\title{
Digging Activity and Estimation of the Population Density of Moles
}

\author{
RYJĄCA AKTYWNOSC A OCENA ZAGESZCZENIA POPULACJI KRETA
}

\section{Jacek GOSZCZYŃSKI}

Goszczyński J.: Digging activity and estimation of the population density of moles. Acta theriol., 28, 20: 328-332 [With 3 Tables)

Examination was made of individual variations in the digging activity of moles over the yearly cycle. Weather and biotope factors were found to exert a modifying effect on the animals' activity. The mean values, which characterize digging activity over a 24-hour period, may (with certain limitations) be used to estimate the density of moles.

[Agricultural Univ., Dept. Game Management, Rakowiecka 26/30, 02-528 Warszawa, Poland]

\section{INTRODUCTION}

Many difficulties are involved when estimating the density of moles (Talpa europaea Linnaeus, 1758), the numbers of these animals being assessed by catching them in either snap-traps or live traps. The main difficulties connected with the trapping method consists in defining the size of the area from which the captured animals orignate and to achieve total capture of all the animals.

The majority of the estimates so far published are, however, relative in character, since numbers the arrived at on the basis of intensification of the external manifestations of moles' activity (volume of earth thrown up, are occupied by molehills etc.; cf. Kryštal, 1934; Turček, 1965; Kuznecov, 1970 and others). As digging activity may vary greatly in time and depends on the type of biotope in which the moles occur (Funmilayo, 1977) and on the age and sex of the individual (Godfrey, 1955; Skoczeń, 1958) it is feared that estimates of numbers based on measurements of digging activity may not be very accurate.

The purpose of this study was therefore to determine whether single individuals vary as to their activity over the yearly cycle, the extent of such variations and consequently to examine the possibility of using digging activity for estimating the density of moles.

\section{STUDY AREA AND METHODS}

The studies were carried out in the green spaces of Warsaw. Areas which were extremely isolated by buildings, road network or extensive space free of other animals were chosen, in which preliminary inspection had indicated that they were occupied by one mole only. At the same time when choosing working stations endeavour was made to obtain considerable diversity of soil coditions and degree of soil cover by vegetation. Repeated observations were made on each working station in order to check that only one individual did in fact occur 
there. If the animal was found to be active during the observations (e.g. throwing up molehills or forming superficial tunnels) in one part of the working station, with simultaneous absence of signs of activity in other parts, and if a similar result was found several times, the area was held to be occupied by one mole only. If this was not the case the station was not used in further studies. The fact that this kind of segregation was correct was revealed by moles from two working stations being killed by dogs during the course of the studies proper, and no digging activity being observed from that time on the given working station.

In addition in four cases single animals of different weight (from 55 to $100 \mathrm{~g}$ ) and sex (three males and one female) were released in areas formerly occupied, as shown by old molehills, by these animals.

\section{Table 1}

Biotopic description of working stations on which digging activity was measured.

\begin{tabular}{|c|c|c|c|c|c|c|}
\hline \multirow{2}{*}{$\begin{array}{l}\text { No. of } \\
\text { working } \\
\text { station }\end{array}$} & \multirow{2}{*}{$\begin{array}{l}\text { Description } \\
\text { of } \\
\text { working } \\
\text { station }\end{array}$} & \multicolumn{4}{|c|}{ Soil conditions } & \multirow[b]{2}{*}{$\begin{array}{l}\text { Description of } \\
\text { vegetation }\end{array}$} \\
\hline & & Compact- & $\begin{array}{l}\text { Propc } \\
\text { fract }\end{array}$ & ion of & $\mathrm{pH}$ in & \\
\hline 1 & Meadow & 2 & 20.7 & 15.9 & 73 & Dense grass cover mea- \\
\hline & & & & & & dow rarely mown \\
\hline 2 & Meadow & 2 & 15.0 & 16.0 & 7.7 & As above \\
\hline 3 & Wasteland & 2 & - & - & - & $\begin{array}{l}\text { Luxuriant ruderal vege- } \\
\text { tation occurring in } \\
\text { clumps }\end{array}$ \\
\hline 4 & $\begin{array}{l}\text { Part of } \\
\text { park }\end{array}$ & 4 & 37.3 & 8.0 & 7.7 & $\begin{array}{l}\text { Very compact lawn } \\
\text { frequently mown with } \\
\text { clumps of perennial } \\
\text { plants }\end{array}$ \\
\hline 5 & $\begin{array}{l}\text { Part of } \\
\text { park }\end{array}$ & 1 & 31.0 & 9.0 & 7.2 & $\begin{array}{l}\text { Bare soil under trees, } \\
\text { scanty clumps of pe- } \\
\text { rennial plants }\end{array}$ \\
\hline 6 & $\begin{array}{l}\text { Sports } \\
\text { ground }\end{array}$ & 3 & 28.3 & 22.3 & 6.9 & $\begin{array}{l}\text { Grass frequently mown, } \\
\text { dense turf }\end{array}$ \\
\hline 7 & $\begin{array}{l}\text { Former } \\
\text { allotments }\end{array}$ & 1 & 15.0 & 8.0 & 6.7 & $\begin{array}{l}\text { Clumps of ruderal plants } \\
\text { occur }\end{array}$ \\
\hline 8 & $\begin{array}{l}\text { Part of } \\
\text { park }\end{array}$ & 1 & 13.3 & 10.6 & 6.3 & $\begin{array}{l}\text { Very scanty grass under } \\
\text { fruit trees }\end{array}$ \\
\hline 8 & $\begin{array}{l}\text { Part of } \\
\text { park }\end{array}$ & 4 & 19.0 & 9.5 & 7.4 & $\begin{array}{l}\text { Compact, frequently } \\
\text { mown lawn with nume- } \\
\text { rous clumps of bushes }\end{array}$ \\
\hline 10 & $\begin{array}{l}\text { Former } \\
\text { allotments }\end{array}$ & 1 & - & - & - & $\begin{array}{l}\text { Not very dense ruderal } \\
\text { vegetation infrequent } \\
\text { grasses }\end{array}$ \\
\hline
\end{tabular}

1 Arbitral estimates according to following scale: 1 - very loose soil, 2 - loose soil, 3 - compact soil, 4 - very compact soil.

During the studies a total of 10 biotopically differing working stations were in use (Table 1), each occupied by one mole. The digging activity of the individual occurring in each working station was then estimated, but before starting actual measurements all the molehills occurring there were marked (either by pieces of paper chopped small, granulated polystyrene, or sprayed paint). After 24 hours length and breadth (or diameter) of all new molehills and superficial tunnels were measured and marked. The whole procedure was repeated after further 
24-hour periods. In the control series from 2 to 10 measurements were made on one working station. The above method was used at each of 7 different times (cf. Table 2) to analyze from 2 to 8 working stations. In July, September and November 1977 soil samples were taken in the vicinity of the molehills, at the same time as the latter were measured. The samples were taken from a depth of about $5 \mathrm{~cm}$, and the percentage of water content found for each sample. The mechanical composition of the soil and its $\mathrm{pH}$ were also defined on the majority of the working stations.

\section{RESULTS AND DISCUSSION}

During the course of a year's observations, moles' activity measured by the size of the area occupied by thrown-up soil, was lowest in late autumn and winter, but for the remainder of the year it was maintained on a more or less similar level (Table 2). Differences between

Table 2

Seasonal variations in the digging activity of moles-area occupied by thrown-up soil ( $\mathrm{m}^{2} /$ day/animal).

\begin{tabular}{|c|c|c|c|c|}
\hline $\begin{array}{l}\text { Inspection } \\
\text { date }\end{array}$ & $\begin{array}{cc}\text { Number of } & \text { Total } \\
\text { working } & \text { measurements } \\
\text { station } & \text { at given } \\
& \text { time }\end{array}$ & $\begin{array}{c}\text { Digging } \\
\text { activity } \\
\text { mean value } \\
\text { (S.D.) }\end{array}$ & $\begin{array}{l}\text { C.V. } \\
(\%)\end{array}$ & $\begin{array}{l}\text { Mean C.V. } \\
\text { within } \\
\text { working } \\
\text { station } \\
(\%)\end{array}$ \\
\hline July 1977 & $(1,2,4-9)$ & $\begin{array}{c}0.2658 \\
(0.0623)\end{array}$ & 23.4 & 52.5 \\
\hline Sept. 1977 & $, 2,4-6,10)$ & $\begin{array}{c}0.2287 \\
(0.0937)\end{array}$ & 41.0 & 29.8 \\
\hline Nov. 1977 & $(1,2,4,5)$ & $\begin{array}{c}0.1518 \\
(0.0829)\end{array}$ & 54.6 & 50.0 \\
\hline Dec. 1977 & $(1,2)$ & $\begin{array}{c}0.0981 \\
(0.0222)\end{array}$ & 22.6 & 141.4 \\
\hline $\begin{array}{l}\text { March, April } \\
\qquad 1978\end{array}$ & $(1-3)$ & $\begin{array}{c}0.2034 \\
(0.0358)\end{array}$ & 17.6 & 36.1 \\
\hline May 1978 & $\begin{array}{c}4 \\
(1-3,5)\end{array}$ & $\begin{array}{c}0.2346 \\
(0.0362)\end{array}$ & 15.4 & 42.5 \\
\hline June 1978 & $\begin{array}{c}3 \\
(1-3)\end{array}$ & $\begin{array}{c}0.2411 \\
(0.0380)\end{array}$ & 15.8 & 26.9 \\
\hline
\end{tabular}

1 Numbers of working stations from Table 1 given in brackets.

September and November 1977 and between December 1977 and April 1978 , calculated on the basis of mean values of all measurements, are statistically significant (in the first case $0.01>p>0.001$ and in the second $0.05>p>0.02$ ). The causes of the decrease in activity are probably to be found in the reduction in soil temperature. Mean 24-hour soil temperature at a depth of $5 \mathrm{~cm}$ during the period of measurements of digging activity was: September $197715.8^{\circ} \mathrm{C}$, November $19775.4^{\circ} \mathrm{C}$, December $1977,-0.1^{\circ} \mathrm{C}$, March $197810.2^{\circ} \mathrm{C}$. Out of the 34 measurements made in November and December 1977 in 4 cases moles formed no new heaps or superficial tunnels at all. Individual variations in 
activity (during the series of measurements within one working station) were usually fairly great, with a tendency to increase in such variation during the autumn-winter period (Table 2).

During the course of these studies investigation was made of the effect of humidity on the superficial soil surface on the moles' activity. Coefficients of correlation for measurements in July, September and November were positive ( $r$ was respectively: $0.44,0.65$ and 0.66 ). Correlations obtained in July and November proved to be statistically significant $(0.05>p>0.02$ and $0.1>p>0.05)$, while the correlation found in September was not significant $(0.2>p>0.1)$. The relations obtained indicate that moles' activity increases with increased soil humidity.

In July and September 1977 and in May and June 1978, that is, during periods when the average activity of moles was similar, calculation was made of the correlation between the proportion of gravel

Table 3

Density of moles (N/ha) estimated by digging activity, in different periods.

\begin{tabular}{lllll}
\hline & March, Apr. & May & Sept. & Oct. \\
\hline $\begin{array}{l}\text { Digging activity value } \\
\text { taken for calculation }\end{array}$ & 0.2034 & 0.2346 & 0.2287 & $0.2287^{1}$ \\
$\begin{array}{l}\text { Areas outside city } \\
\text { Białolęk Meadows }\end{array}$ & 4.3 & 5.8 & 2.6 & 5.3 \\
Młociny Wood & 1.7 & 2.0 & 2.8 & 3.1 \\
$\begin{array}{l}\text { Area on city boundary } \\
\text { Bielany Grove }\end{array}$ & 1.5 & 1.3 & 1.8 & 2.6 \\
Urban areas Soviet & 1.5 & 0.6 & 0.6 & 0.5 \\
Soldiers Cemetery-Park & 1.1 & 1.1 & 0.9 & 0.9 \\
\hline
\end{tabular}

1 Value identical to that in September taken for calculations,

and loam fractions (these fractions exhibited maximum variation in the biotopes examined) and the area occupied by the thrown-up earth. The coefficients of correlation obtained $(r=-0.08$ and $r=-0.33)$ did not significantly differ from zero $(p>0.1)$ in either case, whereas the relation between digging activity and compactness of soil proved to be significant $(r=-0.58,0.1>p>0.05)$.

No confirmation was found during these studies of Mellanby's suggestion (1967) that moles may not dig new tunnels and throw up hills for a long time. In the above author's opinion such situations occur frequently when moles inhabit biotopes with an abundant food supply (invertebrates). The green spaces of Warsaw are abundant in earthworms (Jopkiewicz, person. comm.) but it was rarely found during the inspections made, that there was no activity among moles, such periods occurring only during the late autumn and winter.

The fairly low degree of variation in activity between working stations, despite their diversity (in the sense of soil conditions and degree of vegetation cover of the soil), suggest that the mean values obtained may be used to estimate the density of moles. The reproduction period has, however, been omitted as no data were available on the digging activity of gestating and lactating females or very young 
moles. It is clear from material (12 females) collected on a different occasion that the first gestating females appear in Warsaw towards the end of May, the maximum of pregnancies occurring in June and July, and almost all young moles have become independent by the end of August (Goszczyński, unpublished data). In addition to these three months (June-August) the winter period (November-February), during which variations in activity are very great, was also omitted. Data obtained during the remaining period were used to estimate the density of moles. Measurements were made of the moles' activity (in accordance with the method previously described, but modified by measurements being made at 2-week intervals) in selected urban green spaces in Warsaw and in suburban areas. The results obtained (Table 3) indicate that the density of moles is from $1-6$ individuals/ha. Density is lower in the town than in suburban areas. It must be added here that in many city parks, especially small ones, moles do not occur at all.

Preliminary results point to the possibility of using measurements of digging activity to estimate the density of moles at least during the spring and autumn periods. Mean values describing the activity of one mole should be estimated under different soil conditions from those occurring in Warsaw. It is also necessary to give greater consideration to weather conditions (e.g. the effect of temperature and soil humidity etc.) which may, as has been shown, modify the moles' activity. Decreased digging activity as the result of a mole making use of neighbouring tunnel systems (group effect) should not be expected as the mole is an animal with strong territorial characteristics (Stein, 1950).

\section{REFERENCES}

Funmilayo O., 1977: Distribution and abundance of moles (Talpa europaea L.) in relation to physical habitat and food supply. Oecologia, 30: 277-283. - Godfrey G. K., 1955: A field study of the activity of the mole. Ecology, 36: 678-685. - Kryštal A. F., 1934: K ekologii i selskohozjajstviennomu značeniju krota v pravoberežnoj lesostepi i na polesie Ukrainy. Zool. Ž., 13: 292-308. - Kuznecov G. V., 1970: O rojuščej diejatelnosti kavkaskogo krota (Talpa caucasica). Zool. Ž., 49: 1254 -1257. - Mellanby K., 1967: Food and activity in the mole, Talpa europaea. Nature, 215: 1128-1130. - Skoczen S., 1958: Tunnel digging by the mole (Talpa europaea L.). Acta theriol., 2: 233-249. - Stein G. H. W., 1950: Zur Biologie des Maulwurfs, Talpa europaea L., Bonn. zool. Beitr., 1: 97-116. - Turček F. J., 1965: The role of animals in baring and soil erosion. Acta zool, Acad. Scien. hungaricae, 11: $203-217$.

Accepted, February 25, 1983. 